\title{
CORTISOL AND ANTIDIURETIC HORMONE RESPONSES TO STRESS IN CARDIAC SURGICAL PATIENTS
}

\author{
Yasu Oka, Shigeharu Wakayama, Tsutomu Oyama, Louis R. Orkin, Ronald M. Becker, \\ M. Donald Blaufox and Robert W.M. Frater
}

\begin{abstract}
The hormonal responses to anaesthesia and cardiac surgery were studied in patients undergoing valve or coronary bypass surgery. Marked increases in antidiuretic hormone levels as a result of surgical stress were seen, and were of approximately equal magnitude in both groups. Although both groups also showed marked increases in plasma cortisol levels in response to operations, this response appeared to be relatively blunted in valve surgery patients, especially at the end of operation and in the intensive care unit. This blunted cortisol response may be a manifestation of exhaustion of adrenocortical reserves in valvular surgical patients whose sympathoadrenal system has already been chronically stimulatcd by a low output state.

The important role of the neuroendocrine system in maintaining homeostasis postoperatively has long been recognized; this relative cortisol deficiency may be ætiologically related to poor postoperative recovery in critically ill valvular surgery patients.
\end{abstract}

KEY WORDS: CARDIAC SURGERY, stress response.

A NUMBER OF INVESTIGATORS ${ }^{1-6}$ have indicated that the function of the cardiovascular autonomic nervous system is altered in patients with valvular heart disease. The loss of sympathetic nervous system control associated with depletion of cardiac norepinephrine, when coupled with the impairment in parasympathetic cardiovascular regulation, limits the ability to augment cardiac output by increasing either stroke volume or heart rate. These derangements of the autonomic nervous system may well play critical roles in the limited cardiac response to stress in these patients.

We have also reported studies ${ }^{7-10}$ of neurohumoral and circulatory responses to stress in cardiac surgical patients. Our studies generally indicated that patients with coronary artery disease showed an excitatory sympathetic response to stress, while patients with valvular disease had marginal or limited sympathetic response to stress.

Yasu Oka, M.D., Shigeharu Wakayama, M.D., Tsutomu Oyama, M.D., Louis R. Orkin, M.D., Ronald M. Becker, M.D., M. Donald Blaufox, M.D., and Robert W.M. Frater, M.B., Ch.B. Department of Anesthesiology, Cardiothoracic Surgery and Nuclear Medicine. Albert Einstein College of Medicine, Bronx, New York and Department of Anesthesiology, University of Hirosaki, Hirosaki, Japan.

Reprint requests to Dr. Oka at Albert Einstein College of Medicine, 1300 Morris Park Avenue, Bronx, New York, 10461.

Canad. Anaesth. Soc. J., vol. 28, no. 4, July 1981
The present study was undertaken to evaluate whether cortisol and antidiuretic hormone responses to stress are different in patients with coronary artery disease and valvular disease, as we have previously found in regard to sympathetic response.

\section{Materials AND Methods}

Twenty-two patients undergoing open heart surgery were studied; 12 patients had coronary artery surgery (CAS) and ten had valvular surgery (VS). The patients were otherwise comparable except for a significantly lower ejection fraction in the VS group. (Table I).

Premedication consisted of scopolamine $\left(0.015 \mathrm{mg} \cdot \mathrm{kg}^{-1}\right)$ and morphine sulphate $\left(0.15 \mathrm{mg} \cdot \mathrm{kg}^{-1}\right.$ for coronary patients or $0.10 \mathrm{mg} \cdot \mathrm{kg}^{-1}$ for valvular patients) intramuscularly, one hour before anaesthesia. Anaesthesia was begun at 8-8:30 a.m. Induction was accomplished $3 \mathrm{mg}$ d-tubocurarine and thiopentone sodium $4-5 \mathrm{mg} \cdot \mathrm{kg}^{-1}$, followed by enflurane 0.5 to 2 per cent and oxygen. The trachea was intubated with the aid of succinylcholine $1.5 \mathrm{mg} \cdot \mathrm{kg}^{-1}$ intravenously and following topical application of lidocaine $(4 \%-4 \mathrm{ml})$. Anaesthesia was maintained with enflurane 0.5 to 2 per cent with oxygen, supplemented with either pancuronium or d-tubocurarine. Five per cent dextrose in water was administered at a rate of $10 \mathrm{ml} \cdot \mathrm{kg}^{-1} / \mathrm{hr}$ 334 
TABLE I

Preoperative Patient Characteristics

\begin{tabular}{lrr}
\hline \hline & $\begin{array}{c}\text { Coronary Artery } \\
\text { Surgery }\end{array}$ & $\begin{array}{c}\text { Valvular } \\
\text { Surgery }\end{array}$ \\
\hline Patients No. & 12 & 10 \\
$\quad$ NYHA Class (II) & 7 & 6 \\
& 5 & 4 \\
Age (Year) & $59 \pm 10$ & $59 \pm 9$ \\
Ejection Fraction (\%) & $71 \pm 18$ & $58 \pm 11^{*}$ \\
LVEDP (Torr) & $16 \pm 9$ & $17 \pm 7$ \\
CPB time (min.) & $154 \pm 85$ & $144 \pm 63$ \\
\hline
\end{tabular}

Mean \pm SD *P $<0.05$.

LVEDP: Left Ventricular end-diastolic pressure.

$\mathrm{CPB}=$ Cardiopulmonary bypass.

until the start of cardiopulmonary bypass, and thereafter reduced to $5 \mathrm{ml} \cdot \mathrm{kg}^{-1} / \mathrm{hr}$. A conventional cardiopulmonary bypass (CPB) technique using an Optiflo II (Cobe Laboratories) bubble oxygenator was employed and the patients were cooled to $30^{\circ} \mathrm{C}$ (oesophageal temperature) during $\mathrm{CPB}$. The prime solution consisted of albumin $500 \mathrm{ml}$ and Normoso ${ }^{\boxplus 2} 2000 \mathrm{ml}$.

The study was divided into eight periods: 1 . Control (before induction of anaesthesia); 2. One hour after induction of anaesthesia (before skin incision); 3. Thirty minutes after skin incision (pre-CPB); 4. Fifteen minutes on CPB; 5 . One hour on $\mathrm{CPB} ; 6$. Thirty minutes off $\mathrm{CPB} ; 7$. End of operation and; 8 . One hour postoperative in the intensive care unit.

The following were determined: Plasma cortisol and antidiuretic hormone (ADH) levels, arterial and venous blood gases, serum osmolality and electrolytes, urine output and osmolality. Plasma cortisol levels were determined by the fluorimetric method of Rudd, et al.;" the recovery rate was 102 per cent and the coefficient of variation (CV) was 1.5 per cent. Plasma ADH levels were measured by the radioimmunoassay method of Husain, et al.: $:^{12}$ recovery rate was 74 per cent and CV was 11 per cent. Heparinized venous blood for ADH was immediately iced and centrifuged for 15 minutes at $4^{\circ} \mathrm{C}$. Extraction of plasma samples was done using cold acetone and petroleum ether. Dried plasma extracts were stored at $-20^{\circ} \mathrm{C}$ until assayed. Arginine Vasopressin (AVP) from Sigma Chemical Co. used as a standard for ADH (I-125-AVP) was purchased from New England Nuclear. The micropressor unit (U) is the equivalent of about $2.5 \mathrm{pg}$ of AVP. The packed cell volume (PCV) was measured by the macrohaematocrit method and used to make corrections for the haemodilution effect of plasma cortisol and ADH levels. Serum and urine osmolalities were measured by the freezing point depression method using an Osmette precision osmometer.

Arterial pressure (AP), right and left atrial pressures (RAP, LAP), heart rate (HR) and cardiac output $(\mathrm{CO})$ were recorded. Pressures were measured and recorded continuously through a Statham transducer on a HewlettPackard multichannel recorder (Model 775A). Cardiac output was determined by dye dilution technique using an Electronics for Medicine output computer (Model DTCCO). Systemic vascular resistance (SVR) was calculated from the output and pressure data. Intergroup data were analyzed using the uncorrelated t-test and intragroup data were analyzed using the correlated $\mathrm{t}$-test.

\section{RESULTS}

\section{Coronary Artery Surgery Group}

Enflurane anaesthesia alone did not increase plama cortisol levels significantly. However, surgical stimulation provoked a significant rise of cortisol from the control value of $11.0 \pm 0.9$ to $18.1 \pm 1.6 \mu \mathrm{g} / 100 \mathrm{ml}$ and this increase was sustained during CPB. After CPB there was a steady increase in plasma cortisol levels to a peak value ( 210 per cent of control, $\mathrm{P}<0.01$ ) in the ICU (Figure 1).

The control value of plasma ADH was $5.4 \pm$ $0.7 \mu \mathrm{U} / \mathrm{ml}$. Enflurane did not cause ADH release. Plasma ADH rose significantly after surgical stimulation (290 per cent of control, $\mathrm{P}<0.01)$ and during $\mathrm{CPB}(>300$ per cent of control, $\mathrm{P}<0.01)$. After CPB, the level declined but it stayed significantly elevated compared with the control value. In the ICU, it was 177 per cent of the control value. There were no significant changes in plasma osmolality throughout the study. Plasma sodium levels decreased significantly at the end of operation and plasma potassium decreased significantly during the first 15 minutes on $\mathrm{CPB}$. Urine output increased significantly during and after $\mathrm{CPB}$ in spite of high plasma $\mathrm{ADH}$ levels. Urine osmolality decreased, but not significantly.

Haemodynamic changes are shown in Figure 2. There were no statistically significant changes in any variable except for a significant $(\mathrm{P}<0.01$, $\mathrm{P}<0.05$ ) decrease in MAP and SVR at pre-CPB and during CPB. Cardiac index decreased significantly $(P<0.05)$ at the end of operation.

There was no correlation between plasma cortisol or ADH levels and changes in haemodynamic variables except after 15 minutes on $\mathrm{CPB}$, 


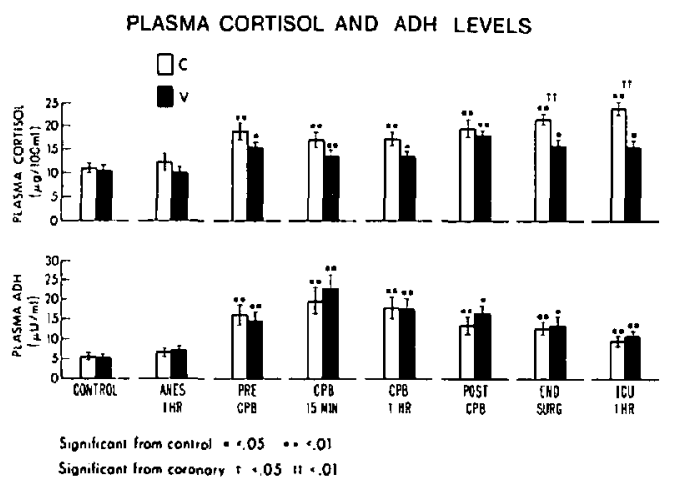

Figure 1 Plasma Cortisol and ADH levels. Top, plasma Cortisol levels in coronary artery and valvular surgical patients. Enflurane anaesthesia alone did not increase plasma levels significantly. Surgical stimulation (Pre CPB) provoked a significant rise of cortisol from the control valve and this increase was sustained during and after CPB to a peak value in the ICU in both groups. However, in general, the response in valvular surgical patients was blunted compared to that of coronary artery surgical patients and a significant difference in plasma levels was noted at the end of operation and ICU periods. Bottom, plasma ADH levels. The changes in ADH levels were identical in both groups and it rose significantly after surgical stimulation and during CPB. After CPB, the level declined but it stayed significantly elevated compared with the control value in both groups.

when MAP and SVR decreased significantly $(\mathrm{P}<$ $0.05)$ associated with increased $A D H$ levels.

\section{Valvular Surgery Group}

The control plasma cortisol level was $10.3 \pm$ $1.0 \mu \mathrm{g} / 100 \mathrm{ml}$ and it increased significantly to 14.8 $\pm 1.1 \mu \mathrm{g} / 100 \mathrm{ml}$ after surgical stimulation. During $\mathrm{CPB}$, the plasma cortisol levels did not increase further. The peak levels of cortisol were seen at the post CPB sampling time and had declined by the end of operation and in the ICU. Haemodynamic changes was similar to CAS group except that cardiac index decreased significantly at one hour of anaesthesia.

\section{Coronary Artery Surgery Group vs Valvular Surgery Group}

The plasma cortisol levels at the end of operation and in the ICU in the VS group were significantly lower $(P<0.05)$ than the levels at the same periods in coronary artery surgical patients. The plasma ADH levels and all biochemical variables were identical to those in coronary patients. Haemodynamic variables did not differ significantly between the groups except that the MAP in valvular patients was significantly lower $(P<0.05)$ compared to coronary patients at the anaesthesia one hour, pre-CPB and ICU periods.

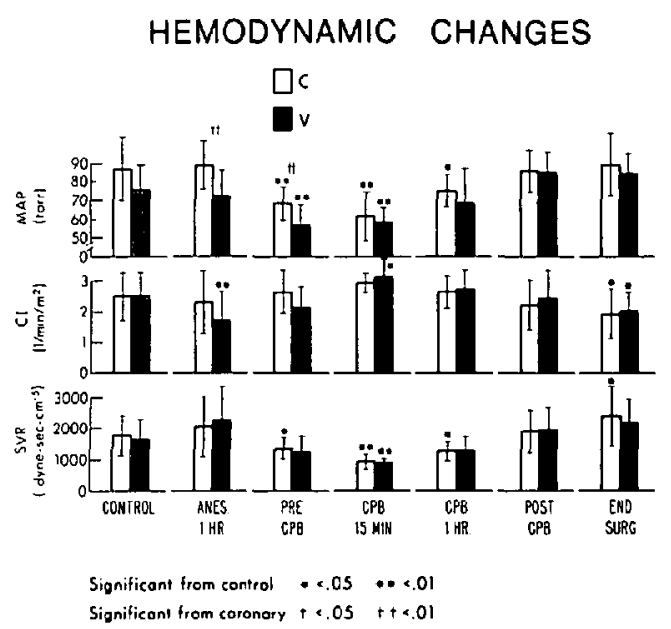

Figure 2 Haemodynamic Changes. Changes in mean artieral pressure (MAP) cardiac index (CI) and systemic vascular resistance ( $S V R$ ) in coronary artery and valvular surgical patients are shown. There were no statistically significant changes in any of those variables except for significant decrease in MAP and SVR at pre and during CPB in both groups. At the end of operation, CI decreased significantly in coronary artery surgical patients associated with a significant increase in SVR.

\section{Discussion}

During open heart surgery, patients are exposed to mechanical circulation, haemodilution and major surgical stress. The output of cortisol and ADH may be influenced by one or more of these factors. Plasma cortisol is an indicator of the magnitude of adrenocortical response to stress. A typical pattern of cortisol response to surgical stress is a brisk rise from resting levels to a peak, with a subsequent return to normal values within a few days. ${ }^{13}$ However, the response of plasma cortisol during CPB is not well defined although many studies have been done. Recently, Taylor, et al.$^{14}$ reported that during CPB the cortisol response differs markedly from the typical response to surgical stress, with a marked fall in plasma cortisol levels at the onset of CPB.

Uozome, et al..$^{15}$ stated that these low levels of cortisol were probably caused by haemodilution. Taylor, et al. ${ }^{16.17}$ suggested the existence of adrenocortical hypofunction during non-pulsatile $\mathrm{CPB}$, due to reduced $\mathrm{ACTH}$ release. On the other hand, Yokota, et al. ${ }^{18}$ reported that cortisol secretion could overcome the dilution effect after 30 minutes on CPB and that the adrenal cortex preserved its responsiveness during $\mathrm{CPB}$ of less than three hours; i.e. the cortisol response to a mechanical circulation during CPB was similar to that occurring during surgical stress with a nor- 
mal circulation. These investigators evaluated plasma cortisol levels in a heterogeneous groups of patients with congenital, valvular and coronary diseases. We evaluated the cortisol response to anaesthesia, surgery and CPB in two separate groups, one with coronary artery discase and the other with valvular disease. In the coronary patients we confirmed the slight fall in plasma cortisol levels during $\mathrm{CPB}$ as seen by Taylor, et al. ${ }^{14}$ However, after $\mathrm{CPB}$, the rise in cortisol levels typical of the usual response to surgery reappears. ${ }^{19}$ The valvular surgical patients show the same pattern but absolute levels were lower throughout operation. During the post CPB and ICU periods, plasma cortisol levels were significantly lower than in coronary artery surgical patients (Figure 1). The difference was not related to difference in serum electrolytes or cardiac output, which decreased significantly to the same extent in both groups. At this period, the only difference was mean arterial pressure in the ICU, being significantly lower in valvular surgical patients than in coronary artery surgical patients $(79.7 \pm 9.0$ vs $88.4 \pm 9.2, \mathrm{P}<0.05)$ Boucher ${ }^{20}$ demonstrated that during CPB adrenal blood flow is increased and it is conceivable that the changes of blood flow and distribution in this gland might compromise its secretory reserve. ${ }^{18}$

The control values for ADH in these groups of patients were slightly higher than the usual accepted values for healthy persons. ${ }^{21}$ This could be due to relative hypovolaemia in our patients because of limitation of fluid intake and, in some cases, chronic administration of diuretics. There was little change in plasma ADH following enflurane anaesthesia in this study and this confirms the report of Oyama, et al. ${ }^{19}$ that enflurane does not affect $A D H$ release. This contrasts with the effects of other agents, such as diethyl ether ${ }^{21}$ and halothane ${ }^{22}$ which increase plasma $A D H$ levels during anaesthesia alone in man. The ADH response to surgical stimulation demonstrated in these patients was also in agreement with reports in the literature, ${ }^{23}$ although the actual levels are lower in our patients. The extent of the ADH response may be related to the depth of anaesthesia ${ }^{24}$ and the anaesthetics used. Simpson, et al. ${ }^{25}$ reported that plasma ADH levels seen during CPB under halothane anaesthesia were higher than in those measured under narcotic anaesthesia. The volume of fluid administered is reported to modify ADH release in general surgery:26 however, haemodilution does not appear to influence $\mathrm{ADH}$ release significantly during $\mathrm{CPB} .{ }^{23}$

The increase in $\mathrm{ADH}$ release seen at the onset of CPB is probably due to the hypotension which is commonly associated with low systemic vascular resistance. The loss of pulsatile flow and rapid decline in mean arterial pressure may be significant factors in ADH release, perhaps as an effort to maintain SVR. The circulatory stress of CPB seems to override the normal osmotic regulation of $\mathrm{ADH}$ levels between 0.05 and $6.0 \mu \mathrm{U} .27 .28$ The ADH levels observed are considered beyond the physiological range for an antidiuretic effect on the kidney; thus paradoxically increased urine output may be related to the changes in circulation. ${ }^{29}$

If $\mathrm{ADH}$ levels beyond the physiological range are reflecting the stress reaction ${ }^{24}$, there may be no difference in degree of stress caused by these two operative procedures because ADH responses to surgical stimulation in both groups were identical. These observations of cortisol and ADH responses suggest that the decline of the plasma cortisol levels at the end of operation in valvular surgical patients may represent a relative exhaustion of adrenal cortical response, as the majority of valvular surgical patients had been under the stress of low output state and their sympatho-adrenal system had chronically been stimulated. Together with the previously demonstrated derangement of the autonomic nervous system in valvular cardiac patients, the comparative cortisol deficiency may be related to relatively poor postoperative recovery seen in critically ill valvular surgical patients, compared to that of patients undergoing coronary artery bypass surgery.

\section{ACKNOWLEDGEMENT}

We are deeply indebted to Hyo B. Lee for the technical assistance.

\section{REFERENCES}

1. Braunwald, E., Editor. The Myocardium: Failurc and Infarction. New York: H.P. Publishing Co page 59 (1974).

2. Chidsay, C.A., Braunwald, E. \& Morrow, A.G. Catecholamine excretion and cardiac stores of norepinephrine in congestive heart failure. Am. J. Med. 39: 422 (1965).

3. Covell, J.W., Chidsay, C.A. \& Braunwald, E. Reduction of the cardiac response to postganglionic sympathetic nervice stimulation in experimental heart failure. Circulatory Research 19:51 (1966).

4. Eckberg, D.L., Drabinsky, M. \& Braunwald, E. Defective cardiac parasympathetic control in patients with heart disease. New Eng. J. Med. 285: 877 (1971).

5. Higgins, C.B., Vatner, S.F., Echberg, D.L. \& Braunwald, E. Alterations in the baroreceptor reflex in conscious dogs with heart failure. J. Clin. Invest. 51: 715 (1972). 
6. Pool, R.E., Covell, J.W., LevitT, M. GibB, J. \& BRaUnwalD. E. Reduction of cardiac tyrosine hydroxylose activity in experimental congestive heart failure. Its role in the depletion of cardiac norepinephrine stores. Cir. Res. 20: 349 (1967).

7. OKA, Y., LiN, Y.T., Yeh, L.C., BEChER, R., FrATER, R.W.M. \& SpECTOR, S. Failure of morphine anesthesia to reduce mycardial $\mathrm{O}_{2}$ demand during coronary artery bypass surgery. Abstract, Am. Soc. Anes. 511 (1977).

8. Bassell, G., Lin, Y.T., OKa, Y. \& Frater, R. Circulatory response to tracheal intubation in patients with coronary artery disease and valvular diease. Bull. N. Y. Acad. Med. 51: 842 (1978).

9. Oka, Y., Frishman, W., Becker, R.M., Kadish, A., Strom, J., Matsumoto, M., Orkin, L.R. \& FRATER, R.W.M. B-adrenoreceptor blockade and coronary surgery. Amer. Heart Jour. 99: 225 (1980).

10. Frater, R.W.M., Wakayama, S., Oka, Y., Becker, R.M., Desal, P., Oyama, T. \& Blaufox. D. Pulsatile cardiopulmonary bypass? Failure to influence hemodynamics and hormones. Circulation 62(I): 19 (1980).

11. Rudd, B.T., Simpson, P.\& Brooke, B.M. A new flurimetric method of plasma cortisol assay with a study of pituitary-adrenal function using Metyapone (SU 4885). Jour. of Endoc. 27: 317 (1963).

12. Husain, M.K., Fernando, N., Shapiro, M., KaGAN, A. \& GLiCK, S.M. Radioimmunoassay of arginine vasopressin in human plasma. Jour. Clin. Endoc. Metab. 37: 616 (1975).

13. Cope, C.L. Adrenal steroids and disease. Philadelphia: J.B. Lippincott, page 197 (1972).

14. TAYLOR, R.M., JONES, J.V., WALKER, M.S., RAO, S. \& BAIN, W.H. The cortisol response during heart-lung bypass. Circulation 54: 20 (1976).

15. Uozone, T., Manabe, H., Kawashima, Y., Yamanuka, Y., Monden, Y. \& Matsumoto, K. Plasma costisol, corticosterone and non-proteinbound cortisol in extracorporeal circulation. Acta Endoc. 69: 517 (1972),

16. TAYOR, K.M., WRIGHT, G.S., REID, J.M., BAIN, W.H., Caves, P.K., Walter, M.S. \& Grand, J.K. Comparative studies of pulsatile and nonpulsatile flow during cardiopulmonary bypass. II. The effects of adrenal secretion of cortisol. $J$. Thorac. Cardiovasc. Surg. 75: 574 (1978).

17. Taylor, K.M., Bremner, W.F., Gray, C.E., RatClifFe, J.G. \& BaIN, W.H. Anterior pituitary function during cardiopulmonary bypass. Brit. J. Surg. 63: 161 (1976).

18. Yokota, H., Kawashima, Y., Hashimoto, S. Manabe, H., Onishi, T., Aono, T. \& MatsuMoTo, K. Plasma cortisol, luteinizing hormone (LH) and prolactin secretory responses to cardiopulmonary bypass. Jour. Surg. Res. 23: 196(1977).

19. Oyama, T., Taniguchi, K., Ishihara, H., Matsuke, A., Maeda, A., Murakawa, T. \& Kudo, $T$. Effects of enflurane anesthesia and surgery on endocrine function in man. Brit. J. Anaesth. 5/: 141 (1979).

20. Boucher, J.K., Lloyd, W.R. \& Edmunds, H. Organ blood flow during pulsatile cardiopulmonary bypass. J. Appl. Physiol. 36: 86 (1974).

21. OYama, T. \& Kimura, K. Plasma levels of antidiuretic hormone in man during diethyl ether anaesthesia and surgery. Canad. Anaesth. Soc. J. 17: 495 (1970)

22. Oyama, T, Sato, K. \& Kimura, K. Plasma levels of antidiuretic hormone in man during halothane anaesthesia and surgery. Canad. Anaesth. Soc. J. 18: 614 (1971).

23. Philbin, D.M. \& Coggins, C.H. Plasma vasopressin levels during cardiopulmonary bypass with and without profound haemodilution. Canad. Anaesth. Soc. J. 25: 282 (1978).

24. Philbin, D.M. \& Coggins, C.H. Plasma antidiuretic hormone levels in cardiac surgical patients during morphine and halothane anesthesia. Anesthesiology 49: 95 (1978).

25. Simpson, P. \& Forsling, M. The effects of halothane on plasma vasopressin during cardiopulmonary bypass. Clin. Endoc. 7: 33 (1977).

26. ISHIMARA, H., ISHITA, K., OYAMA, T. \& KUDO, T. Effects of general anaesthesia on renal function and plasma ADH levels. Canad. Anaesth. Soc. J. 25: 312 (1978).

27. RoBERTSON, G.L. Vasopressin in osmotic regulation in man. Annual Review of Medicinc 25: 315 (1974).

28. Moran, W,R., JR. \& ZimmermanN, B. Mechanism of antidiuretic hormone (ADH) control of importance to the surgical patient. Surgery 62:639 (1967).

29. Philbin, D.M., Coggins, C.H., Wilson, N. \& Sokoloski, J. Antidiuretic hormone levels during cardiopulmonary bypass. J. Thorac. Cardiovasc. Surg. 73: $145(1977)$.

\section{RÉSUMÉ}

Les réponses hormonales à l'anesthésie et à la chirurgie ont fait l'objet de la présente étude effectuée chez un groupe de malades soumis à une chirirgie valvulaire ainsi que chez ceux d'un second groupe subissant une chirurgie coronarienne. On a observé une élévation marquée de l'hormone anti-diurétique secondaire au stress de la chirurgie et cette élévation était semblable chez les patients des deux groupes. Le taux du cortisol s'est également élevé chez les patients des deux groupes en réponse au stress chirurgical, mais cette réponse était atténuée chez les valvulaires, en particulier en fin d'intervention et dans la phase postopératoire immédiate. Une telle réponse chez les valvulaires peut refléter l'épuisement des réserves adreno-corticales chez des patients dont le système adreno-sympathique a été stimulé de façon chronique par la présence d'un bas débit cardiaque.

Le rôle important du. systeme neuro-endocrinien dans le maintien du l'homoéostase post-opératoire est connu depuis longtemps; la déficience relative en cortisol peut contribuer à une évolution post-opératoire difficile chez des patients en condition critique. 